\title{
HUBUNGAN ANTARA KOPING RELIGIUS DENGAN BURNOUT PADA GURU SMK SWASTA X KOTA SEMARANG
}

\author{
Nur Dania Muhandisatin Nadhilah dan Ratna Supradewi \\ Fakultas Psikologi Universitas Islam Sultan Agung, Jl. Kaligawe Raya km 4, Genuk, Kota Semarang \\ E-mail:nrdaniamn@gmail.com, ratnavina4@gmail.com
}

\begin{abstract}
Abstrak
Penelitian ini bertujuan untuk mengetahui hubungan antara koping religius dengan burnout pada guru SMK swasta X kota Semarang. Subjek dalam penelitian ini yaitu guru SMK swasta X kota Semarang, berjumlah 57 orang. Teknik pengambilan sampel menggunakan teknik sampling jenuh (sampling sensus) dengan cara mengambil keseluruhan populasi. Pengumpulan data menggunakan skala burnout yang terdiri dari 35 aitem dengan koefisien reliabilitas 0,91 dan skala koping religius yang terdiri dari 22 aitem dengan kooefisien reliabilitas yang bergerak pada rentang $0.720-0.890$. Penelitian ini menggunakan metode kuantitatif korelasional dan menggunakan analisis data statistik product moment. Berdasarkan hasil analisis statistik diperoleh nilai $r_{x y}=-0,444$ dengan taraf signifikansi $p=0.001(p \leq 0.005)$. Hasil penelitian menunjukkan bahwa ada hubungan negatif antara koping religius dengan burnout pada guru SMK swasta X kota Semarang. Sumbangan efektif dari koping religius yang mempengaruhi burnout sebesar $19,7 \%$ berdasarkan Rsquare sebesar 0.197 , sedangkan $80.3 \%$ dipengaruhi oleh faktor lain.
\end{abstract}

Kata Kunci: burnout, koping religious

\section{RELATIONSHIP BETWEEN RELIGIOUS COPING AND BURNOUT FOR PRIVATE VOCATIONAL SCHOOL TEACHERS X AT SEMARANG CITY}

\begin{abstract}
This study aims to determine the relationship between religious coping and burnout in private vocational school teachers $x$ at Semarang city. The subjects in this study were private vocational school teachers $x$ in Semarang city, totaling 57 people. The sampling technique used a saturated sampling technique (census sampling) by taking the entire population. The data were collected using a burnout scale consisting of 35 items with a reliability coefficient of 0.91 and a religious coping scale consisting of 22 items with a reliability coefficient that moves in the range $0.720-0.890$. This study uses correlational quantitative methods and uses product moment statistical data analysis. Based on the results of statistical analysis, it was obtained that the value of $r_{x y}=-0.444$ with a significance level of $p=0.001$ ( $p \leq 0.005)$. The results showed that there was a negative relationship between religious coping and burnout in private vocational school teachers $x$ at Semarang City. The effective contribution of religious coping which affected burnout was $19.7 \%$ based on the Rsquare of 0.197 , while $80.3 \%$ was influenced by other factors.
\end{abstract}

Keywords: burnout, religious coping 


\section{Pendahuluan}

SMK atau Sekolah Menengah Kejuruan merupakan sekolah yang dituntut agar dapat menghasilkan siswa-siswa lulusan yang mampu bersaing dalam dunia kerja dan kompetitif. Siswa lulusan sekolah menengah kejuruan disiapkan agar dapat langsung terjun ke dalam dunia kerja, siswa dibekali softskill dan lifeskill dalam pembelajaran yang nantinya menjadi modal untuk masuk ke dalam dunia kerja. Berdasarkan hal tersebut guru yang berkompeten dibutuhkan guna diharapkan dapat menghasilkan siswa lulusan sekolah menengah kejuruan yang dapat mampu bersaing dalam dunia kerja dan dapat lebih kompetitif (Rahmaningtyas, Baedhowi, \& Santosa, 2013). Dalam pendidikan, guru merupakan unsur manusiawi. Guru adalah sosok sumber yang memegang suatu peranan dan memiliki posisi yang penting di dalam pendidikan (Djamarah, 2010). Tugas guru yaitu antara lain adalah sebagai contoh terhadap perilaku siswa, sebagai mentor, dan sebagai tutor (Natalia \& Supramono, 2011). Dalam Undang-Undang Republik Indonesia nomor 14 tahun 2005, guru adalah seorang pendidik profesional yang memiliki tugas utama untuk mendidik, membimbing, mengajar, melatih, mengarahkan, menilai, dan melakukan evaluasi terhadap peserta didik dalam pendidikan menengah, pendidikan dasar, dan pendidikan anak usia dini dalam jalur pendidikan yang formal. Profesi guru menurut Maslach dan Jackson merupakan salah satu wujud dari human service profession atau bentuk pelayanan kemanusiaan yang terdapat banyak tantangan (Wardhani, 2012).

Berbagai macam tuntutan, tekanan, serta banyak melibatkan suatu emosi merupakan sesuatu yang sering dihadapkan kepada guru sebagai profesi yang menggeluti bidang kemanusiaan. Tekanan yang ada dan tuntutan yang ada dapat berasal dari luar seperti berasal dari siswa, dan dapat berasal dari dalam diri guru sendiri (Natalia \& Supramono, 2011). Menurut Sutjipto (Natalia \& Supramono, 2011) mengemukakan bahwa pengalaman yang negatif dengan siswa yang terkadang dihadapkan pada guru dapat menimbulkan suatu ketegangan emosional. Keadaan secara akumulatif dan berlangsung terus-menerus tersebut dapat membuat terkurasnya sumber energi yang dimiliki guru. Tenaga edukatif yang terkuras sumber energi tersebut dapat mengalami kelelahan emosi. Sedangkan berdasarkan hasil penelitian Kyriacou (Natalia \& Supramono, 2011) menunjukkan bahwa rendahnya motivasi pada siswa dan kurang disiplinnya siswa dapat menimbulkan tekanan bagi guru. Selain hal itu, berapa lama waktu bergelut dalam profesi guru ternyata dapat terkesan monoton dan dapat memunculkan kejenuhan (Natalia \& Supramono, 2011). Gambaran mengenai kerumitan kondisi psikologis dan kondisi fisik yang ada akibat terdapat tekanan yang ada dari luar dan dalam diri sesorang dikenal dengan istilah stres (Prawitasari, 2011). Stres yang dialami oleh seseorang yang bekerja secara berhadapan langsung dengan manusia sebagai bentuk pelayanan kemanusiaan menurut Maslach dan Jackson (1981) disebut sebagai istilah burnout.

Burnout menurut Ivancevich, Konopaske, dan Matteson (2007) yaitu proses psikologi yang disebabkan oleh stres terhadap pekerjaan yang berlanjut dan menimbulkan kelelahan secara emosi, kepribadian yang berubah, dan turunnya perasaan terhadap pencapaian. Penelitian terkait dengan burnout telah banyak dilakukan dan telah berpusat dengan yang disebut sebagai "profesi pembantu" seperti dokter, perawat, petugas pengawasan pembebas bersyarat, polisi, ahli terapi, pekerja sosial, dan guru.

Menurut hasil penelitian Natalia dan Supramono (2011) terhadap 81 guru yang ada di Palangka Raya, hasil penelitian menunjukkan bahwa $88 \%$ guru cenderung menilai burnout pada kategori yang tinggi. Dalam hasil penelitian, persepsi yang tinggi terhadap burnout mengindikasikan adanya sebagian besar dari subjek penelitian yang mengalami sindrom burnout (Natalia \& 
Supramono, 2011). Menurut Natalia dan Supramono (2011) hasil tersebut terwakili dengan indikator bahwa sebagai guru selalu terkuras dengan cara emosional, merasa jenuh dan bosan, mengalami kelelahan fisik, serta bekerja seharian penuh dengan orang banyak menjadi stres.

Timbulnya stres yang mengarah ke burnout pada guru diduga didorong dengan banyaknya tuntutan dan tekanan yang ada pada individu (Natalia \& Supramono, 2011). Menurut Pines dan Aronson, burnout adalah suatu pengalaman secara subjektif adanya kelelahan secara kondisi fisik, mental dan emosional sebagai akibat dari keterlibatan dalam situasi yang berlangsung dalam jangka panjang yang menuntut emosi. Individu yang mengalami burnout secara perlahan semangatnya terkikis yang disebabkan stres kronis terkait pekerjaan yang selalu dilakukan sehari-hari, seperti banyaknya tekanan, tuntutan, konflik dan kurang adanya reward emosi, kesuksesan serta pengakuan (Natalia \& Supramono, 2011).

Menurut hasil penelitian Purba, Yulianto, dan Widyanti (2007), salah satu faktor yang menunjukkan perbedaan burnout pada guru yaitu jenjang pendidikan tempat bekerja. Mengajar di jenjang pendidikan SMA gejala burnout lebih rentan dialami oleh guru daripada mengajar di jenjang pendidikan SD dan SMP. Hal ini dapat disebabkan karena adanya perbedaan beban kerja yang ada pada guru di jenjang pendidikan SMA dengan guru di jenjang pendidikan SMP dan SD. Guru yang mengajar di jenjang pendidikan SMA berhadapan dengan siswa yang memiliki karakeristik lebih kompleks serta beban tugas yang cenderung lebih banyak dapat mengakibatkan guru menjadi burnout.

Maslach, Schaufeli dan Leiter (2001) menyebutkan dampak dari burnout yaitu berkaitan dengan absensi kehadiran, niat untuk mengundurkan diri atau meninggalkan pekerjaan, dan turnover. Burnout cenderung menyebabkan penurunan efektivitas dan produktivitas dalam bekerja bagi individu yang bertahan dengan pekerjaan yang ada. Konsekuensi dari hal tersebut juga berkaitan dengan berkurangnya komitmen terhadap organisasi atau pekerjaan dan adanya penurunan terhadap kepuasan kerja. Mengingat burnout terkait dengan stres, dampak dari burnout dapat mengganggu kesehatan. Terdapat asumsi secara umum yang menyebutkan bahwa burnout menyebabkan disfungsi mental, burnout memicu efek negatif terkait kesehatan mental seperti penurunan harga diri, kecemasan, depresi, dan lain sebagainya (Maslach, Schaufeli, \& Leiter, 2001).

Stres dan burnout merupakan dua konsep yang tidak sama namun mirip. Terjadinya burnout disebabkan oleh adanya proses adaptasi yang secara terus-menerus terhadap gangguan yang muncul karena ketidakseimbangan dalam waktu yang lama. Sedangkan terjadinya stres disebabkan oleh ketidakseimbangan antara sumber daya yang individu miliki dengan tuntutan yang berasal dari lingkungan. Stres dan burnout juga menimbulkan efek yang berbeda. Stres dapat menimbulkan efek positif dan juga efek negatif, sedangkan burnout hanya menimbulkan efek-efek negatif seperti munculnya perilaku yang negatif dan penurunan hasrat akan pencapaian diri sendiri (Purba, Yulianto, \& Widyanti, 2007).

Salah satu faktor yang dapat mempengaruhi burnout adalah strategi koping (Maslach, Schaufeli, \& Leiter, Job burnout, 2001). Dalam konsep kesehatan mental menurut Siswanto (2007), istilah koping dikenal sebagai penyesuaian diri dalam mengadapi stres. Koping dimaknai sebagai sesuatu yang dilakukan oleh seseorang untuk menguasai situasi yang dianggap sebagai suatu ancaman, tantangan, luka, ataupun kehilangan. Jadi Koping lebih merujuk pada apa yang orang lakukan sebagai sesuatu untuk mengatasi tuntutan yang membangkitkan emosi atau penuh tekanan. Dengan kata lain, koping adalah bagaimana respon atau reaksi seseorang ketika menghadapi tekanan 
atau stres yang ada (Siswanto, 2007). Menurut Lazarus dan Folkman koping merupakan suatu bentuk pikiran, usaha, serta suatu tindakan yang berfungsi dalam mengatasi suatu situasi yang penuh tekanan atau situasi aversif (Angganantyo, 2014).

Berdasarkan hasil penelitian yang dilakukan oleh Wardhani (2012) terkait dengan burnout di kalangan guru pendidikan luar biasa adalah adanya hubungan negatif antara perilaku koping dengan burnout yang signifikan. Hal ini berarti semakin tidak efektif atau buruknya perilaku koping yang digunakan maka burnout yang dialami semakin tinggi (Wardhani, 2012).

Dalam kehidupan seseorang, koping dapat dikembangkan kedalam banyak aspek kehidupan. Pendekatan agama merupakan salah satu bentuk coping dari berbagai macam bentuk koping yang ada (Angganantyo, 2014). Dalam agama tersedia suatu strategi koping yang unik (Juniarly \& Hadjam, 2012). Koping dengan menggunakan pendekatan agama atau religius disebut dengan koping religius (Angganantyo, 2014).

Menurut Koenig, dkk (Juniarly \& Hadjam, 2012) koping religius yaitu perilaku atau penggunaan keyakinan keagamaan sebagai sebagai sarana pemecahan masalah dan mengurangi atau mencegah konsekuensi negatif dari suatu kondisi emosional kehidupan yang penuh dengan tekanan atau stres. Sedangkan koping religius menurut Wong dan Wong (dalam Angganantyo, 2014) yaitu strategi coping yang didalamnya dimasukkan pemahaman akan kekuatan yang berkaitan dengan unsur keTuhanan sebagai pemahanan terhadap sesuatu kekuatan dalam hidup yang sangat besar.

Koping religius tergolong masih jarang digunakan dalam penelitian terkait dengan burnout. Sebagian besar penelitian yang ada cenderung mengorelasikan hubungan antara burnout dengan strategi koping secara umum seperti strategi koping yang berfokus pada masalah dan koping yang berfokus pada emosi. Dalam penelitian ini yang membedakan dengan penelitian sebelumnya adalah akan mengorelasikan variabel koping religius dengan burnout pada guru di SMK swasta X kota Semarang.

\section{Metode Penelitian}

Metode yang akan digunakan dalam pengumpulan data pada penelitian ini yaitu metode kuantitatif dengan menggunakan teknik analis data product moment. Adapun alat pengumpulan data, peneliti menggunakan skala dengan cara penyebaran secara langsung mengunjungi sekolah menengah kejuruan swasta yang menjadi sample penelitian. Penelitian ini menggunakan dua skala, yaitu skala pertama adalah skala burnout yang disusun oleh Avionela dan Fauziah (2016) dengan berdasarkan aspek-aspek yang dikemukakan oleh Maslach, Leiter, dan Schaufeli yang meliputi emotional exhaustion (kelelahan emosi), depersonalization (depersonalisasi), reduced personal accomplishment (menurunkan pencapaian pribadi). Pada skala burnout koefisien reliabiltas yaitu 0.91. Skala burnout terdiri dari 35 item. Skor tinggi burnout yang diperoleh menunjukkan bahwa semakin tinggi burnout, dan sebaliknya semakin rendah skor yang diperoleh maka menunjukkan semakin rendahnya burnout. Skala yang kedua adalah skala koping religius dari Aflakseir dan Coleman (2010) yang di alih bahasa melalui beberapa tahap. Skala pada penelitian ini melalui tahap alih bahasa yang terjemahkan oleh Kurnia Citra Dewi, S.Pd., M.Pd. dari lembaga ahli bahasa CILAD Universitas Islam Sultan Agung. Selanjutnya peneliti menerjemahkan kembali kepada Anisa Fitriani, S. Psi, M. Psi. dosen Fakultas Psikologi Universitas Islam Sultan Agung dan kemudian mendapat persetujuan dari dosen pembimbing. Aspek yang meliputi dalam skala koping religius ini yaitu, 
strategi koping religius aktif (active religious coping strategy) dengan reliabilitas 0.790 , strategi koping religius pasif (passive religious coping strategy) dengan reliabilitas 0.720 , penilaian penuh kebijakan (religious benevolent reapprasial) dengan reliabilitas 0.790 , perasaan negatif terhadap Tuhan (negative feeling toward God) dengan reliabilitas 0.790, praktek agama (religious practice) dengan reliabilitas 0.890 . Skala koping religius terdiri dari 22 item. Skor tinggi koping religius yang diperoleh menunjukkan bahwa semakin tinggi koping religius, dan sebaliknya semakin rendah skor yang diperoleh maka menunjukkan semakin rendahnya koping religius.

\section{Hasil dan Pembahasan}

Peneliti secara langsung melakukan penelitian terkait hubungan antara koping religius dengan burnout pada 57 orang guru SMK swasta di kecamatan X kota Semarang dengan jumlah data subjek yang dapat dilihat pada tabel 1 sebagai berikut:

Tabel 1. Jumlah Subjek Tiap Sekolah Menengah Kejuruan

\begin{tabular}{lll}
\hline No & Nama Sekolah & Jumlah \\
\hline 1 & SMK Robbi Rodliyya & 11 \\
2 & SMK Cut Nya Dien & 22 \\
3 & SMK Kartika Nusantara & 9 \\
4 & SMK Hisba Buana & 15 \\
& Total & 57 \\
\hline
\end{tabular}

Setelah data terkumpul dilakukan uji asumsi dengan menggunakan Statistic Product and Service Solution (SPSS) versi 16.00. Uji asumsi ini meliputi uji normalitas dan uji linearitas yang dilakukan sebelum analisis data. Uji normalitas dilakukan dengan bertujuan untuk mengetahui distribusi pada setiap variabel yang ada normal atau tidak normal. Data hasil uji normalitas dapat dilihat pada tabel 2 sebagai berikut:

Tabel 2. Hasil Analisis Uji Normalitas

\begin{tabular}{lllllll}
\hline Variabel & Mean & Std. Deviasi & KS-Z & Sig & $\mathbf{p}$ & Keterangan \\
\hline Burnout & 66.28 & 10.549 & 1.116 & 0.166 & $>0,05$ & Normal \\
Koping Religius & 69.56 & 5.44 & 1.051 & 0.219 & $>0,05$ & Normal \\
\hline
\end{tabular}

Berdasarkan data hasil uji normalitas, pada variabel burnout diperoleh nilai KS-Z 66.28 dengan taraf signifikansi $0.166(p>0,05)$ dan pada variabel koping religius diperoleh nilai KS-Z 69.56 dengan taraf siignifikansi 0.219 ( $p>0.05$ ). Berdasarkan hasil analisis uji normalitas ini menunjukkan bahwa skala pada kedua variabel burnout dan koping religius memiliki distribusi sebaran data yang normal.

Tahap selanjutnya adalah uji liniearitas yang bertujuan untuk mengetahui hubungan antar variabel. Data hasil uji linearitas antar variabel dapat dilihat pada tabel 3 sebagai berikut:

Tabel 3. Hasil Uji Linearitas

\begin{tabular}{lllll}
\hline Variabel & Flinear $_{\text {Sig. }}$ & Sig. & $\mathbf{p}$ & Keterangan \\
\hline Koping Religius - Burnout & 13.5 & 0.001 & $\leq 0.005$ & Linear \\
\hline
\end{tabular}


Berdasarkan data hasil uji linearitas diperoleh nilai $\mathrm{F}_{\text {linear }}=13.5$ dengan taraf signifikansi 0.0001 ( $p \leq 0.005$ ). Hasil uji linearitas ini menunjukkan bahwa koping religius dengan burnout memiliki hubungan yang linear membentuk garis lurus.

\section{Burnout}

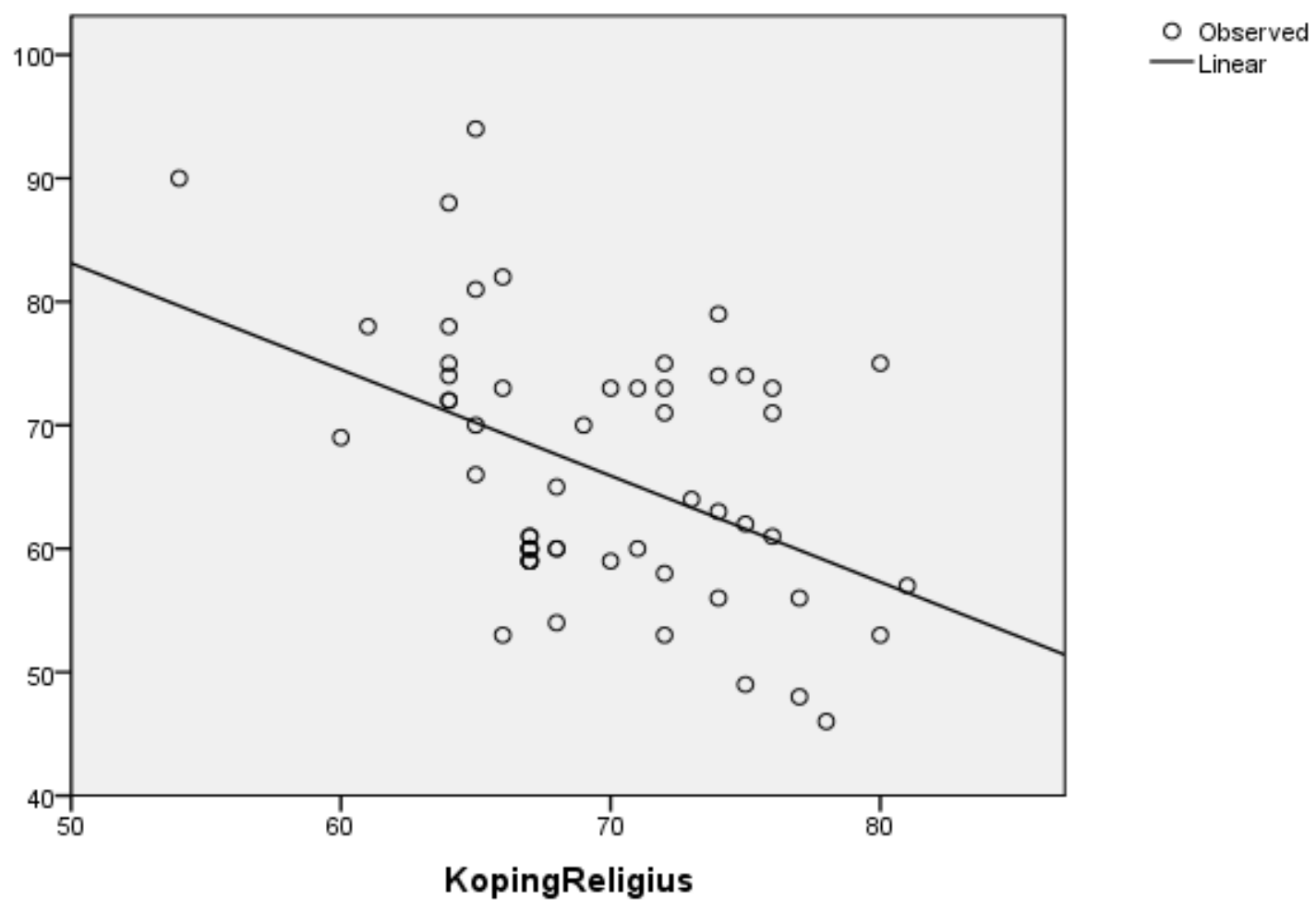

Gambar 1. Kurva Hasil Uji Linieritas

Uji hipotesis dalam penelitian ini menggunakan teknik analisis Pearson product moment. Teknik analisis korelasi Pearson product moment digunakan untuk menguji apakah ada hubungan negatif antara koping religius dengan burnout pada guru SMK swasta di Kecamatan X kota Semarang. Uji hasil korelasi dapat dilihat pada tabel 4 sebagai berikut:

Tabel. 4 Hasil Uji Korelasi

\begin{tabular}{llll}
\hline & & Burnout & Koping Religius \\
\hline Burnout & Pearson Correlation & 1 & -0.444 \\
& Sig. (2-tailed) & & 0.001 \\
& N & 57 & 57 \\
\multirow{4}{*}{ Koping Religius } & Pearson Correlation & -0.444 & 1 \\
& Sig. (2-tailed) & 0.001 & \\
& N & 57 & 57 \\
\hline
\end{tabular}


Berdasarkan hasil perhitungan SPSS dengan teknik analisis product moment, korelasi pada $r_{\mathrm{xy}}=-$ 0.444 dengan taraf signifikansi 0.001 ( $p \leq 0.005)$ menunjukkan bahwa terdapat adanya hubungan negatif antara koping religius dengan burnout pada guru SMK swasta di kecamatan X kota Semarang. Hasil uji hipotesis memperlihatkan bahwa hipotesis dalam penelitian ini diterima.

Deskripsi data dalam penelitian ini dimaksudkan untuk menyampaikan gambaran terkait keadaan deskripsi skor skala pada subjek yang diukur dalam penelitian. Deskripsi data juga guna untuk menjadi informasi tentang kondisi subjek dalam penelitian terhadap variabel yang diteliti. Pengelompokkan berupa kategorisasi ini guna untuk menempatkan subjek penelitian kedalam kelompok-kelompok tertentu terpisah secara berjenjang berdasarkan atribut yang diukur.

Deskripsi skor berdasarkan hasil penelitian (empirik) pada skala burnout diperoleh skor minimum yaitu 46 , skor maksimum 94, mean empirik yaitu 66.28, dan standar deviasi empirik sebesar 10.55. Deskripsi skor skala burnout dapat diperjelas pada tabel 3 sebagai berikut :

Tabel 3. Deskripsi Skor Skala Burnout

\begin{tabular}{lll}
\hline Norma & Empirik & Hipotetik \\
\hline Skor Minimum & 46 & 35 \\
Skor Maksimum & 94 & 140 \\
Mean (M) & 66.28 & 87.5 \\
Standar Deviasi & 10.55 & 17.5 \\
\hline
\end{tabular}

Nilai rata-rata empirik pada subjek penelitian berdasarkan norma kategorisasi pada skala burnout diperoleh 66.28 dimana nilai rata-rata hipotetik yang diperoleh sebesar 87.5. Hal ini menunjukkan bahwa rata-rata skor pada subjek penelitian berada dalam kategori rendah dengan skor 66.28 yang dapat dilihat pada tabel 4 sebagai berikut:

Tabel 4. Kategorisasi Distribusi Normal

\begin{tabular}{llll}
\hline Norma & Kategori & Jumlah Subjek & \% \\
\hline $119<x \leq 140$ & Sangat Tinggi & 0 & $0 \%$ \\
$98<x \leq 119$ & Tinggi & 0 & $0 \%$ \\
$77<x \leq 98$ & Sedang & 8 & $14 \%$ \\
$56<x \leq 77$ & Rendah & 42 & $\mathbf{7 3 . 7 \%}$ \\
$35<x \leq 56$ & Sangat Rendah & 7 & $12.3 \%$ \\
Jumlah & & $\mathbf{5 7}$ & $\mathbf{1 0 0 \%}$ \\
\hline
\end{tabular}

\begin{tabular}{|c|c|c|c|c|}
\hline Sangat Rendah & Rendah & Sedang & Tinggi & Sangat Tinggi \\
\hline 35 & & & 77 & 98 \\
\hline
\end{tabular}


Berdasarkan dari rentang skor pada skala burnout dapat dideskripsikan bahwa 7 subjek dalam penelitian ini berada pada skor burnout sangat rendah, 42 subjek dalam penelitian ini berada pada skor burnout rendah, dan 8 subjek dalam penelitian ini berada pada skor burnout sedang.

Deskripsi skor berdasarkan hasil penelitian (empirik) pada skala koping religius diperoleh skor minimum yaitu 54, skor maksimum 81 , mean empirik yaitu 69.56, dan standar deviasi empirik sebesar 5.44. Deskripsi skor skala koping religius dapat diperjelas pada tabel 5 sebagai berikut :

Tabel 5. Deskripsi Skor Skala Koping Religius

\begin{tabular}{lll}
\hline Norma & Empirik & Hipotetik \\
\hline Skor Minimum & 46 & 22 \\
Skor Maksimum & 94 & 88 \\
Mean (M) & 69.56 & 55 \\
Standar Deviasi & 5.44 & 11 \\
\hline
\end{tabular}

Nilai rata-rata empirik pada subjek penelitian berdasarkan norma kategorisasi pada skala koping religius diperoleh 69.56 dimana nilai rata-rata hipotetik yang diperoleh sebesar 55 . Hal ini menunjukkan bahwa rata-rata skor pada subjek penelitian berada dalam kategori tinggi dengan skor 69.56 yang dapat dilihat pada tabel 6 sebagai berikut:

Tabel 6. Kategorisasi Distribusi Normal

\begin{tabular}{llll}
\hline Norma & Kategori & Jumlah Subjek & $\%$ \\
\hline $74.8<x \leq 88$ & Sangat Tinggi & 12 & $21 \%$ \\
$61.6<x \leq 74.8$ & Tinggi & 42 & $73.7 \%$ \\
$48.4<x \leq 61.6$ & Sedang & 3 & $5.3 \%$ \\
$35.2<x \leq 48.4$ & Rendah & 0 & $0 \%$ \\
$22<x \leq 35.2$ & Sangat Rendah & 0 & $0 \%$ \\
Jumlah & & 57 & $100 \%$ \\
\hline
\end{tabular}

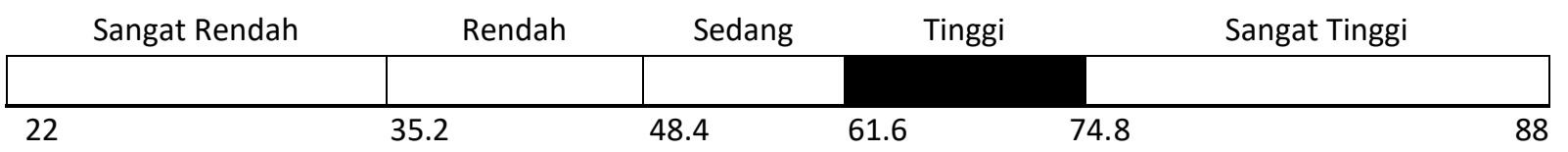

Gambar 3. Rentanng Skor Skala Koping Religius

Berdasarkan dari rentang skor pada skala koping religius dapat dideskripsikan bahwa 12 subjek dalam penelitian ini berada pada skor koping religius sangat tinggi, 42 subjek dalam penelitian ini berada pada skor koping religius tinggi, dan 3 subjek dalam penelitian ini berada pada skor koping religius sedang.

\section{Pembahasan}

Tujuan dalam penlitian ini adalah untuk mengatahui hubungan antara koping religius dengan burnout pada guru SMK swasta X kota Semarang. Hasil dari analisis uji hipotesis yang telah dilakukan dengan menggunakan teknik korelasi product moment diketahui bahwa terdapat hubungan antara 
koping religius dengan burnout. Hal ini dapat diketahui dengan melihat nilai pada $\mathrm{rxy}=-0.444$ dengan taraf signifikansi $0.001(p<0,005)$. Hasil analisis uji menunjukkan bahwa terdapat hubungan negatif yang signifikan antara koping religius dengan burnout pada guru SMK swasta $\mathrm{X}$ kota Semarang. Apabila semakin tinggi koping religius dilakukan oleh guru, maka semakin rendah tingkat burnout yang dialami oleh guru. Sumbangan efektif berdasarkan hasil penelitian ini sebesar 19,7\% berdasarkan Rsquare sebesar 0.197 , sedangkan $80.3 \%$ dipengaruhi oleh faktor lain.

Penelitian ini sejalan dengan hasil penelitian yang telah dilakukan Azkiati, Rahman dan Fahmi (2019) yang menyatakan bahwa koping religius memiliki pengaruh negatif pada burnout. Dalam penelitian tersebut menyatakan bahwa untuk mengantisipasi terjadinya burnout dapat dengan cara meningkatkan koping religius. Penelitian Aflakseir dan Mahdiyar (2016) juga menunjukkan hasil bahwa semakin besar penggunaan koping religius berkaitan dengan rendahnya tingkat depresi.

Menurut Koenig (dalam Aflakseir dan Coleman 2011) koping religius merupakan suatu cara dalam mengelola stres secara emosional maupun ketidaknyamanan secara fisik, dengan menggunakan perilaku atau strategi kognitif yang didasarkan pada keyakinan atau praktik keagamaan. Koping religius merupakan suatu cara yang dilakukan seseorang dengan berdasarkan agama dan keyakinan untuk mengatasi situasi yang penuh dengan tekanan. Hasil penelitian Carpenter, Mezulis, dan Laney (dalam Azkiati, Rahman dan Fahmi 2019) juga menunjukkan bahwa koping religius memberikan pengaruh dalam mengurangi depresif dan gejala-gejala stres. Burnout sendiri merupakan proses psikologi yang disebabkan oleh stres terhadap pekerjaan yang berlanjut dan menimbulkan kelelahan secara emosi, kepribadian yang berubah, dan turunnya perasaan terhadap pencapaian (Ivancevich, Konopaske, \& Matteson, 2007). Menuruut Maslach, Leiter, Schaufeli (2001) koping religius termasuk salah satu faktor yang mempengaruhi burnout.

Adapun kelemahan dalam penelitian ini yaitu peneliti tidak mendapatkan ini pada salah satu sekolahan untuk menyerahkan secara langsung skala pada setiap guru dan hanya mendapatkan ijin untuk menitipkan skala penelitian pada pihak sekolah, sehingga kurang adanya observasi langsung dalam pengisian skala.

\section{Kesimpulan}

Berdasarkan hasil dari penelitian yang telah dilakukan menunjukkan bahwa terdapat hubungan negatif yang signifikan antara koping religius dengan burnout pada guru SMK swasta $X$ kota Semarang. Hal ini berarti bahwa semakin tinggi koping religius dilakukan oleh guru, maka semakin rendah tingkat burnout yang dialami oleh guru.

Berdasarkan hasil dan proses penelitian yang telah dilakukan, diharapkan bagi guru untuk tetap dapat meningkatkan pengelolaan koping religius, seperti meningkatkan praktik ibadah dan keyakinan, sehingga dapat mempertahankan rendahnya tingkat burnout. Peneliti selanjutnya diharapkan dapat melakukan penelitian terkait burnout dari lingkungan yang berbeda.

\section{Daftar Pustaka}

Angganantyo, W. (2014). Coping religius pada karyawan muslim ditinjau dari tipe kepribadian. Jurnal IImiah Psikologi Terapan, 02, 50-61.

Djamarah, S. B. (2010). Guru dan anak didik dalam interaksi edukatif (suatu pendekatan teoritis psikologis). Jakarta: PT Rineka Cipta. 
Nur Dania Muhandisatin Nadhilah dan Ratna Supradewi

Ivancevich, J. M., Konopaske, R., \& Matteson, M. T. (2007). Perilaku dan manajemen organisasi (1 ed.). (G. Gania, Penerj.) Jakarta: Penerbit Erlangga.

Juniarly, A., \& Hadjam, M. N. (2012). Peran koping religius dan kesejahteraan subjektif terhadap stres pada anggota bintara polisi di polres kebumen. Psikologika, 17, 5-16.

Maslach, C., Schaufeli, W. B., \& Leiter, M. P. (2001). Job burnout. Annual Review Psychology, 52, 397422.

Natalia, K., \& Supramono. (2011). Pengaruh budaya organisasi, self-efficacy dan strategi coping proaktif terhadap burnout. Jurnal Ekonomi dan Bisnis, XVI, 35-44.

Prawitasari, J. E. (2011). Psikologi klinis: pengantar terapan mikro dan makro. Jakarta: Penerbit Erlangga.

Purba, J., Yulianto, A., \& Widyanti, E. (2007). Pengaruh dukungan sosial terhadap burnout pada guru. Jurnal Psikologi, 5, 77-87.

Rahmaningtyas, W., Baedhowi, \& Santosa, J. (2013). Kompetensi guru sekolah menengah kejuruan (SMK) dalam implementasi kurikulum tingkat satuan pendidikan (KTSP). Jurnal Pendidikan Insan Mandiri, 1, 34-41.

Siswanto. (2007). Kesehatan mental: konsep, cakupan, dan perkembangannya. Yogyakarta: Penerbit Andi.

Wardhani, D. T. (2012). Burnout di kalangan guru pendidikan luar biasa di kota Bandung. Jurnal Psikologi Undip, 11, 73-82. 